Biological and Clinical Sciences Research Journal

ISSN: 2708-2261

www.bcsrj.com

DOI: https://doi.org/10.54112/bcsri.v2020i1.32

Biol. Clin. Sci. Res. J., Volume, 2020: 32

Original Research

\title{
IMPACT OF PUBLIC EXTENSION SERVICES FOR EFFECTIVE WEED MANAGEMENT PRACTICES IN WHEAT-MAIZE CROPPING PATTERN IN FAISALABAD PUNJAB, PAKISTAN
}

\section{SAEED MM, CHAUDHRY KM, ASHRAF I, *USMAN M, EJAZ R, SHOAIB M, RIAZ I}

\author{
Institute of Agricultural Extension, Education and Rural Development, University of Agriculture, Faisalabad, \\ Punjab, Pakistan \\ Corresponding author: malikusmanuaf@gmail.com
}

(Received, $18^{\text {th }}$ July 2020, Revised $16^{\text {th }}$ September 2020, Published $25^{\text {th }}$ September 2020)

\begin{abstract}
Weeds infestation is one of the major bottlenecks for higher productivity and responsible for considerable grain losses up to $18 \%$ in Wheat and 10-60\% in Maize crop. Weeds are problematic because of their faster growth and competition for use of natural resources. To ascertain the impact of different public extension services working for improvement of farmer's knowledge to effective weed management in wheat-maize cropping pattern present was conducted in district Faisalabad. Results of present study evaluated that a vast majority (64.7\%) of farmers were familiar with farm and home visit, (46.3\%) farmers were known to telephone call and less than one fifth (12.5\%) were conversant with office call in individual contact extension services. Meanwhile only (1.5\%) farmers were aware with personal letter as a public extension service. In group contact methods more than one fourth (40\%) were conscious with farmer day and field day but a meager percentage (2.2\%) were known to buzz group and brain storming extension services in reference to effective weeds control. Almost (75\%) farmers were recognized with television, mobile phone and fellow farmers as a beneficial agricultural extension services. Majority of farmers were aware about pesticide dealers as a first source of information. According to mean value (2.00) individual contact method was tending between very low to low rates of effectiveness for proper weeds management. Almost (50\%) farmers were satisfied with group contact methods as an effective public extension services. Mobile phone was considered most helpful method for obtaining proper information related to weeds control having (3.40) mean value in present research. After getting these types of results it was suggested that provision of the relevant information and awareness regarding effective weeds management may only be ensured if a combination of different contact methods is brought under implementation comprehensively. Language barriers must need to be minimized while contacting the farmers and command over local language and terms is one of the major ways forward in this regard. However further studies are required to investigate the rate of effectiveness of local herbicides.
\end{abstract}

Keywords: extension services, buzz group, fellow farmers, integrated weeds management, cropping pattern

\section{Introduction}

Agriculture sector contributes significantly towards the reduction of poverty, increasing food security, economic growth and rural development in all over the world. Agriculture is the main source of income for 2.5 billion populations of throughout globe. The 8 Millennium Development Goals of World Bank one of them is to eradicate poverty and hunger through advancements in agricultural sector (World Bank, 2008). Weed infestation is a very serious problem as it can reduce $25-40 \%$ yield of wheat, $45 \%$ of maize, $20-50 \%$ of cotton, $10-20 \%$ of potato and up to $20-$ $25 \%$ of rice by using the productivity of land in the form of nutrients and water through root zones. Different types of cropping systems are being practiced in various districts of the Punjab. Major cropping systems are rice-wheat, cotton-wheat, wheat-maize, rice-potato and cotton-maize etc. in
Punjab (Bhatti et al., 2006). Weeds are the plants which compete for nutrients, space, light and exerts lot of harmful effects by reducing the quality as well as quantity of the crop, if, the weed populations are left uncontrolled (Arnold et al., 1988; Halford et al., 2001). Maize is one of the world's major cereal crops, ranking third in importance after wheat and rice (Lashkari et al., 2011). Weeds regularly cause devastating maize crop losses (Bajwa et al., 2015). In under developing countries $70 \%$ production of wheat, maize and rice crops are low because farmers use traditional methods of crop production. Over all world losses to different weeds are considerable specially in African countries (Muzari et al., 2012). There is a need to adopt weed control practices that precisely, both for economic and environmental reasons (Bilalis et al. 2003). Barros et al. (2008) reported that the aim of weed management is to keep the weed community at an acceptable level rather

[Citation: Saeed, M.M., Chaudhry, K.M., Ashraf, I., Usman, M., Ejaz, R., Shoaib, M. and Riaz, I. (2020). Impact of public extension services for effective weed management practices in wheat-maize cropping pattern in Faisalabad Punjab, Pakistan. Biol. Clin. Sci. Res. J., 2020: 32. doi: https://doi.org/10.54112/bcsrj.v2020i1.32] 
than to keep the crop totally free of weeds. Relevant and timely dissemination of information packages to the farmers played an important role to increase production and improvement in marketing policies (Cartmell et al., 2004). Information sources are divided in two categories as interpersonal and impersonal. Face to face contact between people fall in interpersonal and mass media sources fall in impersonal information sources (Muhammad, 2005).

Different research findings have shown that many sources of information effect on adoption for modern agricultural technology and practices. These communication sources include Mass media (Newspaper, magazines, radio, and television) which played a significant role for awareness about technology and adoption at early stages. While interpersonal method of communication (extension agents, crop consultant, input suppliers, demonstration and other growers) have also a significant role for the adoption of advanced technologies (Mcbride et al., 2003). Agriculture extension department has many important functions like the creation of awareness about new agricultural technologies and to give training about technical skills etc. Different sources of information are being used by department of agriculture extension includes meetings, group discussions, result demonstration, lecture, leaflets, bulletins, television, radio, and letters. To fulfill the requirements of rapidly increasing the population production of agriculture should be increased. This can be done by adopting latest techniques of farming (Okunade, 2007). However, the role of new information technologies cannot be excluded. It is necessary for agricultural development to enhance the per acre yield, improving the marketing system and strategies about distribution, in agriculture extension fellow farmers, print media are prominent sources of information for farming community (Rehman et al., 2013). Agricultural extension is a system, which facilitates the farmers to increase agricultural productivity. Different educational procedures are being used to train and enable famers to improve their agricultural practices, farming techniques; increase yield production and increase revenue; improving living standards, and uplifting the social, economic and educational standards (Rehman et al., 2013). Adoption rate of farmers about new technology is necessary to obtain sustainability. Farmers and Extension field staff get most of their training from Non-Governmental Organization's about adoption of new innovations that depends on their own information and discussions with neighbors when making decision about crop production (Martin et al.,
2013). However, the majority of local farmers depending on traditional methods of production due to lack of information and poor extension skills. To check the role of public extension services for effective weed management present study was designed.

\section{Methodology}

It was quite difficult and problematic to conduct the research at entire population due to shortage of resources e.g. time, energy and cost. Hence, the researcher had chosen a part of population for her study rather to conduct research at entire population. Faisalabad is $3^{\text {rd }}$ most populated district in Pakistan their old name of Faisalabad was Layyalpur. It is $2^{\text {nd }}$ largest district in eastern Punjab District Faisalabad consists of six number of tehsils, two are rural and four urban. Among rural Tehsils, Chak Jhumra was selected purposively which consists of 13 union councils and 4 rural Union councils among 13 UCs were selected purposively. From each (UCs) two villages were selected by using simple random sampling. All the wheat-maize growing farmers were the population of the research. Farmers' lists practicing wheat and maize cropping pattern in selected villages were collected from Department of Agriculture (Extension wing) Faisalabad. From each selected villages 17 farmers were selected randomly thus by making a sample size of 136 . The sample size was derived by using online software (www.Surveysystem.com) with confidence level 95\% and confidence interval 5\%. The main objective of this study was to check the role of public extension services for effective weed management practices in wheat-maize cropping pattern in Faisalabad Punjab, Pakistan. These were the parameters of our current study: Awareness about public extension services and Extent of benefits of public extension services.

\section{Results and Discussion}

This results described the demographic characteristics (age, education, tenancy status, land holding, farming experience and area under wheat and maize crop etc.), of the respondents and their awareness level regarding different weeds of wheat and maize crops.

\section{Awareness about individual and group contact method}

Information sources play a special role for creating awareness among farmers. Farmers get their basic and latest knowledge from different public and private extension services to improve their agricultural production. Role of new information sources cannot be excluded. It is necessary for agricultural and rural development to enhance the per acre yields, improving the marketing system and

[Citation: Saeed, M.M., Chaudhry, K.M., Ashraf, I., Usman, M., Ejaz, R., Shoaib, M. and Riaz, I. (2020). Impact of public extension services for effective weed management practices in wheat-maize cropping pattern in Faisalabad Punjab, Pakistan. Biol. Clin. Sci. Res. J., 2020: 32. doi: https://doi.org/10.54112/bcsrj.v2020i1.32] 
working strategies of extension field staff (Okunade, 2007). To check the awareness about extension contact methods were divided in to two categories (i) individual contact method and (ii) group contact methods

Table 1. Awareness level of farmers about Individual and Group contact methods

\begin{tabular}{lll}
\hline Individual contact & \multicolumn{2}{c}{ Awareness } \\
Methods & Yes & No \\
\hline Farm and Home Visits & 64.7 & 35.3 \\
Office Call & 12.5 & 87.5 \\
Personal Letter & 1.5 & 98.5 \\
Telephone Call & 46.3 & 53.7 \\
Group Contact Methods & & \\
Group Meetings & 52.2 & 47.8 \\
Lecture Meetings & 18.4 & 81.6 \\
Discussion Meetings & 8.1 & 91.9 \\
Demonstration & 11.0 & 89.0 \\
Farmer day & 44.9 & 55.1 \\
Field day & 49.4 & 59.6 \\
Field trips and Tour & 23.5 & 76.5 \\
Case study & 5.9 & 94.1 \\
Role playing & 9.6 & 90.4 \\
Brainstorming & 2.9 & 97.1 \\
Buzz Group & 2.2 & 97.8 \\
\hline
\end{tabular}

Data depicted in table 1 describe that majority $(64.7 \%)$ respondents have awareness about farm and home visit. Slightly less than half $(46.3 \%)$ were familiar with telephone call, meanwhile (12.5\%) were known to office call for individual contact. Only $(1.5 \%)$ respondents were aware about personal letter for individual contact with extension field staff. Slightly little more than half $(52.2 \%)$ respondents were aware about group meetings and only (18.4\%) farmers were known to lecture meeting for group contact methods. Results described that slightly less than half $(44.9 \%)$ and $(49.4 \%)$ were aware about farmer day and field day for group contact with public extension field staff. Majority of farmers were unaware about brainstorming, role playing, case study and buzz group due to low working efficiency of public extension field staff. Only (8.1\%) respondents were aware to discussion meetings with extension officer for group contact methods.

Awareness level of farmers about Mass contact methods and other information sources

Different sources of information are used in agriculture, which includes meetings, group discussion, result demonstration, lecture, leaflets, bulletins, television, radio, and letters. To fulfil the requirements of fast increasing the population and the production of agriculture has to be increased. In agriculture extension fellow farmers, print media are prominent sources of information for farming community (Rehman et al., 2013). Information sources have been divided in two categories as interpersonal and impersonal. Face to face contact between people fall in interpersonal meanwhile mass media sources fall in impersonal.

Table 2. Awareness about Mass contact methods and other sources

\begin{tabular}{lcc}
\hline Mass Contact & \multicolumn{2}{c}{ Awareness } \\
Methods & Yes & No \\
\hline Radio & 11 & 89.0 \\
T V & 69.9 & 30.1 \\
Internet & 19.1 & 80.9 \\
Telephone & 2.9 & 97.1 \\
Mobile phone (cell) & 94.1 & 5.9 \\
Helplines & 35.3 & 64.7 \\
Newspaper & 31.6 & 68.4 \\
Magazines & 5.9 & 94.1 \\
Pamphlets & 10.3 & 89.7 \\
Leaflets & 20.6 & 79.4 \\
Signboards & 27.2 & 72.8 \\
Fellow farmers & 98.5 & 1.5 \\
EPS of public sector & 81.6 & 13.3 \\
EPS of private sector & 90.4 & 9.6 \\
Pesticides dealers & 98.5 & 1.5 \\
Exhibitions & 18.4 & 81.6 \\
Campaigns & 5.1 & 94.9 \\
\hline
\end{tabular}

The information given in above table 2 describe that overwhelming majority $(94.1 \%)$ farmers were familiar with Mobile phone (cell) for agriculture related information. Television is also common method for disseminating of modern technologies, majority $(69.9 \%)$ farmers were aware about this information source. In mass contact category only (11\%) farmers were known to radio, (19.1\%) were familiar with internet and meager $(2.9 \%)$ were aware with Telephone for getting agriculture information especially effective weeds management in wheat and maize crop. Almost $100 \%$ farmers were aware about fellow farmers as a main source of getting agricultural information. Awareness percentage about Extension field staff of public and private sector was 81.6 and $90.4 \%$ respectively in other information source category. The results described that majority of farmers $(98.5 \%)$ pesticide related information from pesticides dealers. Only (18.4\%) and $(5.1 \%)$ farmers were aware about exhibitions and campaigns as source of information from agriculture extension department.

Extent of Effectiveness of Public Extension services

In modern agriculture different extension methods are being used to control weeds; farmers use these

[Citation: Saeed, M.M., Chaudhry, K.M., Ashraf, I., Usman, M., Ejaz, R., Shoaib, M. and Riaz, I. (2020). Impact of public extension services for effective weed management practices in wheat-maize cropping pattern in Faisalabad Punjab, Pakistan. Biol. Clin. Sci. Res. J., 2020: 32. doi: https://doi.org/10.54112/bcsrj.v2020i1.32] 
sources on the basis of their traditional knowledge. The extent of effectiveness of public extension services are dependent on their working strategy and knowledge level of farmers.

Table 3. Extent of effectiveness of Individual and Mass contact method

\begin{tabular}{|c|c|c|c|c|}
\hline $\begin{array}{l}\text { Individual } \\
\text { Contact } \\
\text { Method }\end{array}$ & $\begin{array}{c}\text { Weighted } \\
\text { Score }\end{array}$ & $\begin{array}{l}\text { Rank } \\
\text { Order }\end{array}$ & Mean & $\begin{array}{l}\text { Standard } \\
\text { Deviation }\end{array}$ \\
\hline $\begin{array}{l}\text { Farm and } \\
\text { Home Visits }\end{array}$ & 211 & 1 & 2.72 & 0.760 \\
\hline $\begin{array}{l}\text { Telephone } \\
\text { Call }\end{array}$ & 177 & 2 & 2.42 & 0.801 \\
\hline Office Call & 32 & 3 & 1.68 & 1.002 \\
\hline $\begin{array}{l}\text { Personal } \\
\text { Letter }\end{array}$ & 2 & 4 & 1.00 & 0.000 \\
\hline \multicolumn{5}{|c|}{ Group Contact Methods } \\
\hline $\begin{array}{l}\text { Group } \\
\text { Meetings }\end{array}$ & 189 & 1 & 2.55 & 0.813 \\
\hline Field day & 141 & 2 & 2.38 & 0.809 \\
\hline Farmer day & 140 & 3 & 2.37 & 0.740 \\
\hline $\begin{array}{l}\text { Field trips } \\
\text { and Tour }\end{array}$ & 59 & 4 & 2.03 & 0.731 \\
\hline $\begin{array}{l}\text { Lecture } \\
\text { Meetings }\end{array}$ & 55 & 5 & 2.20 & 0.816 \\
\hline Demonstration & 33 & 6 & 2.75 & 0.753 \\
\hline $\begin{array}{l}\text { Discussion } \\
\text { Meetings }\end{array}$ & 23 & 7 & 2.09 & 0.539 \\
\hline Role playing & 23 & 8 & 2.09 & 0.943 \\
\hline Case study & 12 & 9 & 1.50 & 0.755 \\
\hline Buzz Group & 7 & 10 & 1.40 & 0.547 \\
\hline Brainstorming & 6 & 11 & 1.50 & 0.577 \\
\hline
\end{tabular}

Data presented in table 3 describe that most of the farmers were getting information through farm/home visits and telephone calls among individual contact methods having 2.72 and 2.42 mean value respectively. Office call and personal letter were perceived less effective by the respondents having 1.68 and 1.00 mean value. Among group contact methods, group meetings came forward as one of the most effective strategies to disseminate information among the respondents with a mean value of 2.55. Field day, farmer's day, and field trips secured mean effectiveness value of 2.37, 2.03 and 2.20 respectively. Dissemination of the relevant information in mother language of the respondents was perceived to be the most effective way out to reach them effectively in terms of providing the relevant information. Moreover, lecture meetings, demonstration and discussion meetings strategies secured a mean effectiveness value of 2.20, 2.75, and 2.09 respectively. Role playing, case study, buzz group and brainstorming were perceived less effective by the respondents with a mean value of $2.09,1.50,1.40$ and 1.50 respectively.

Extent of effectiveness of Mass contact method and other information sources

Different public and private extension services providing to opportunities to farmers for awareness about effective weeds control. Public extension services provided to farmers were divided in to different categories (i) Individual contact, (ii) Group contact, (iii) Mass contact method (iv) print media and other information sources. The modern agricultural technology was delivered through different sources in which mobile phones and TV were on top of the list. Majority of farmers had awareness about these methods. The effectiveness of these extension services have been given in table 4 .

Table 4. Extent of effectiveness of Mass contact method and other information sources

\begin{tabular}{|c|c|c|c|c|}
\hline $\begin{array}{l}\text { Mass } \\
\text { Contact } \\
\text { Method }\end{array}$ & $\begin{array}{l}\text { Weighted } \\
\text { Score }\end{array}$ & Rank & Mean & $\begin{array}{l}\text { Standard } \\
\text { Deviation }\end{array}$ \\
\hline $\begin{array}{l}\text { Mobile phone } \\
\text { (cell) }\end{array}$ & 420 & 1 & 3.30 & 0.750 \\
\hline $\mathrm{T} \mathrm{V}$ & 227 & 2 & 2.31 & 0.712 \\
\hline Help lines & 85 & 3 & 1.88 & 0.958 \\
\hline Internet & 43 & 4 & 1.79 & 0.883 \\
\hline Radio & 16 & 5 & 1.33 & 0.651 \\
\hline Telephone & 10 & 6 & 2.00 & 1.000 \\
\hline \multicolumn{5}{|l|}{ Print Media } \\
\hline Newspapers & 92 & 1 & 2.13 & 0.861 \\
\hline Leaflets & 73 & 2 & 2.51 & 0.687 \\
\hline Signboards & 72 & 3 & 2.11 & 0.728 \\
\hline Pamphlets & 37 & 4 & 2.31 & 0.793 \\
\hline Books/Booklets & 22 & 5 & 2.44 & 0.726 \\
\hline Magazines & 16 & 6 & 2.28 & 1.112 \\
\hline \multicolumn{5}{|c|}{ Other Information Sources } \\
\hline $\begin{array}{l}\text { Fellow } \\
\text { farmers }\end{array}$ & 475 & 1 & 3.51 & 0.771 \\
\hline $\begin{array}{l}\text { Pesticide } \\
\text { dealers }\end{array}$ & 412 & 2 & 3.09 & 0.786 \\
\hline $\begin{array}{l}\text { EFS of } \\
\text { private sector }\end{array}$ & 361 & 3 & 2.88 & 0.785 \\
\hline EFS of public & & 4 & & \\
\hline $\begin{array}{l}\text { sector (Agri. } \\
\text { Dept.) }\end{array}$ & 262 & & 2.36 & 0.979 \\
\hline Exhibitions & 39 & 5 & 1.69 & 0.764 \\
\hline Campaigns & 13 & 6 & 1.62 & 0.916 \\
\hline
\end{tabular}

The information given in above table 4 indicates that Mobile phone is most effective method for dissemination of agriculture information having 3.30 mean value meanwhile $\mathrm{TV}$ was ranked on $2^{\text {nd }}$ on the basis of their effectiveness according to 2.31 mean value. In mass contact method helplines, internet and

[Citation: Saeed, M.M., Chaudhry, K.M., Ashraf, I., Usman, M., Ejaz, R., Shoaib, M. and Riaz, I. (2020). Impact of public extension services for effective weed management practices in wheat-maize cropping pattern in Faisalabad Punjab, Pakistan. Biol. Clin. Sci. Res. J., 2020: 32. doi: https://doi.org/10.54112/bcsrj.v2020i1.32] 
radio were on $3^{\text {rd }}, 4^{\text {th }}$ and $5^{\text {th }}$ ranked having low rate of effectiveness. In print media category leaflets, signboards, pamphlets and newspapers were comparatively better sources of information for the farmers with a perceived effectiveness value of 2.13 , $2.11,2.31$, and 2.13 respectively. Illiterate farmers were not satisfied with booklets and magazines due to low educational level. Fellow farmers were perceived to be the most reliable and accessible sources of information by majority of the respondents with a mean effectiveness value of 3.51. Pesticides dealers and extension field staff of private sector were also considered prominent sources of information with mean effectiveness value of 3.09 and 2.88 respectively. Extension field staff of public sector, exhibitions, and campaigns secured a perceived effectiveness mean value of 2.36, 1.69 and 1.62 respectively. However, fellow farmers came forward as a major source of information most of the farmers rely on.

\section{Summary and conclusions}

The awareness level of the respondents about individual contact methods was satisfactory and majority of the respondents were aware about office call and only two of the respondents had an idea about personal letter. An overall awareness percentage The other method was group contact; more than $50 \%$ farmers were about group meeting less than half had awareness about farmer day, field day. Farmers had less awareness about buzz group, brainstorming, and case study. The respondents had low awareness and interest towards office call and personal letter as methods of contact. Group meetings, field day and farmers' day were perceived comparatively better contact methods regarding effective weeds management by the farmers. The effectiveness of different contact methods is dependent on their awareness level among farming community therefore, brainstorming, buzz group, case study and role playing were perceived less effective by the respondents. The agriculture related information can effectively be transferred through mass contact method, in which mobile phone might be a potential method to reach out the farmers if proper planning and implementation is ensured. Among mass contact methods TV and internet were perceived better sources of information with contrast to radio and other mass contact methods. Internet source of information was associated with comparatively literate audience while radio was one of the reliable sources of information for the illiterate audience. Even newspapers, leaflets, signboards were also among the sources which had an association with the literate farmers. As a whole illiterate respondents were not satisfied with the contact methods associated with print media.

\section{Recommendations}

$>$ First of all, there is need to create awareness among the farming community about different weeds of wheat and Maize crop, their extent of damage and concept of integrated weeds management.

$>$ Provision of information and awareness to the farmers is directly associated with the way of contacting the farmers. Therefore, there is need to develop a proper mechanism of reaching out the farmers in a proper way.

$>$ There is need to focus on the methods best perceived by the farmers so that effective communication with the farmers must be ensured.

$>$ Farm visits, farmers' days, fellow farmers, phone calls, television, radio and demonstrations are a few of the traditional contact methods perceived best by the farmers. Therefore, their utilization in an effective way may result in better dissemination.

$>$ Establishment of demonstration plots with implication of integrated weeds management practices may contribute effectively towards efficient weeds control.

$>$ There is need to properly train the farmers and EFS as well about using the modern contact methods like ICT's. It would really be helpful in terms of making a difference regarding timely and effective information dissemination.

$>$ Establishing a strong researchers-extension field staff-farmer's linkage through a common contact channel must be ensured so that effective information provision could be exercised

\section{Conflict of interest}

The authors declared absence of any conflict of interest.

\section{References}

Arnold, R.N., M.W. Murray, E.J. Gregory and D. Smeal, (1988). Effects of herbicides on weeds in field corn grown on coarse-textured soils. Journal of Applied Agricultural Research, 3: 121-123.

Bajwa, A.A., Mahajan, G., Chauhan, B.S., 2015. Nonconventional weed management strategies for modern agriculture. Weed Science. 63: $723 \mathrm{e} 747$.

Barros, J.F.C., G. Basch, and M. de-Carvalho (2008). Effect of reduced doses of a post-emergence graminicide to control Avena sterilis L. and Lolium rigidum $\mathrm{G}$. in no-till wheat under

[Citation: Saeed, M.M., Chaudhry, K.M., Ashraf, I., Usman, M., Ejaz, R., Shoaib, M. and Riaz, I. (2020). Impact of public extension services for effective weed management practices in wheat-maize cropping pattern in Faisalabad Punjab, Pakistan. Biol. Clin. Sci. Res. J., 2020: 32. doi: https://doi.org/10.54112/bcsrj.v2020i1.32] 
Mediterranean environment. Crop Protection, 27: 1031-1037.

Bhatti, I.H., Ahmad, R., Jabbar, A., Nazir, M.S., and Mahmood, T. (2006). Competitive behavior of component crops in different sesame legume intercropping systems. International Journal of Agriculture and Biology. 8:165-167.

Bilalis, D., N. Sidiras, G. Economou and C. Vakali, (2003). Effect of different levels of wheat straw soil surface coverage on weed flora in Vicia faba crops. Journal of Agronomy and Crop Science, 189: 233-241.

Cartmell, D. D., Orr, C. L., \& Kelemen, D. B. (2004). Methods of information dissemination to limited-scale land owners. Oklahoma State University. InProceedings of the 31st Annual National Agricultural Education Research Conference, St. Louis, MO 2004.

Halford, C., A.S. Hamill, J. Zhang and C. Doucet, (2001). Critical period of weed control in notill soybean (Glycine max) and corn (Zea mays L). Weed Technology, 15: 737-744.

Lashkari, M., Madani, H., Ardakani, M.R., Golzardi, F., Zargari, K. (2011). Effect of plant density on yield and yield components of different Corn (Zea mays L.) hybrids. Journal of Agriculture and Environmental Sciences. 10, $450 \mathrm{e} 457$.

Martin, R.J., Brown, S., and R. Johnstone (2013). Integrating agricultural adoption pathways in North-Western Cambodia. International Journal of. Environmental and Rural Development. 4, 112e117.

McBride, D. William and G. Stan (2003). Information and the Adoption of Precision Farming Technologies, Journal of Agribusiness, 21: 21-38.

Muhammad, S (2005). Agricultural Extension: Strategies and Skills. 2nd Ed. Unitech Communications, Faisalabad, Pakistan.

Muzari, W. Gatsi, W \& Muvhunzi, S. (2012). The Impacts of Technology Adoption on Smallholder Agricultural Productivity in Sub-Saharan Africa: A Review, Journal of Sustainable Development; 5: 8.

Okunade, E.O. (2007). Effectiveness of extension teaching methods in acquiring knowledge, skill and attitude by women farmers in Osun State. Journal of Applied Sciences and Research, 3(4), 282-286.

Rehman, F., S. Muhammad, I. Ashraf. and S. Hassan (2013). Factors affecting the effectiveness of print media in the dissemination of agricultural information. Sarhad Journal Agriculture, 27(1), 119-124.

World Bank (2008). Millennium Development Goals. www.worldBank.org/mdgs/povertyhunger.html

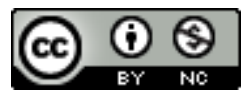

Open Access This article is licensed under a Creative Commons Attribution 4.0 International License, which permits use, sharing, adaptation, distribution and reproduction in any medium or format, as long as you give appropriate credit to the original author(s) and the source, provide a link to the Creative Commons licence, and indicate if changes were made. The images or other third party material in this article are included in the article's Creative Commons licence, unless indicated otherwise in a credit line to the material. If material is not included in the article's Creative Commons licence and your intended use is not permitted by statutory regulation or exceeds the permitted use, you will need to obtain permission directly from the copyright holder. To view a copy of this licence, visit http://creativecommons.org/licen ses/by/4.0/.

(C) The Author(s) 2020

[Citation: Saeed, M.M., Chaudhry, K.M., Ashraf, I., Usman, M., Ejaz, R., Shoaib, M. and Riaz, I. (2020). Impact of public extension services for effective weed management practices in wheat-maize cropping pattern in Faisalabad Punjab, Pakistan. Biol. Clin. Sci. Res. J., 2020: 32. doi: https://doi.org/10.54112/bcsrj.v2020i1.32] 